\title{
Kinase inhibitors in the treatment of immune-mediated disease
} Apostolos Kontzias ${ }^{1}$, Arian Laurence ${ }^{1}$, Massimo Gadina ${ }^{2}$ and John J. O'Shea ${ }^{1 *}$

\author{
Addresses: ${ }^{1}$ Molecular Immunology and Inflammation Branch, National Institute of Arthritis and Musculoskeletal and Skin Diseases, National \\ Institutes of Health, Bethesda, MD 20892, USA; ${ }^{2}$ Translational Immunology Section, Office of Science and Technology, National Institute of \\ Arthritis and Musculoskeletal and Skin Diseases, National Institutes of Health, Bethesda, MD 20892, USA \\ * Corresponding author: John J. O'Shea (osheajo@mail.nih.gov) \\ Fl000 Medicine Reports 2012, 4:5 (doi:10.34I0/M4-5) \\ This is an open-access article distributed under the terms of the Creative Commons Attribution-Non Commercial License \\ (http://creativecommons.org/licenses/by-nc/3.0/legalcode), which permits unrestricted use, distribution, and reproduction in any medium, \\ provided the original work is properly cited. You may not use this work for commercial purposes. \\ The electronic version of this article is the complete one and can be found at: http://fl 000.com $/ \mathrm{reports} / \mathrm{m} / 4 / 5$

\begin{abstract}
Protein kinases are fundamental components of diverse signaling pathways, including immune cells. Their essential functions have made them effective therapeutic targets. Initially, the expectation was that a high degree of selectivity would be critical; however, with time, the use of "multikinase" inhibitors has expanded. Moreover, the spectrum of diseases in which kinase inhibitors are used has also expanded to include not only malignancies but also immune-mediated diseases. At present, thirteen kinase inhibitors have been approved in the United States, all for oncologic indications. However, there are a growing number of molecules, including several Janus kinase inhibitors, that are being tested in clinical trials for autoimmune diseases such as rheumatoid arthritis, psoriasis and inflammatory bowel diseases. It appears likely that this new class of immunomodulatory drugs will have a major impact on the treatment of immune-mediated diseases in the near future.
\end{abstract}

\section{Introduction}

Work over the last 20 years has firmly established that reversible protein phosphorylation is a fundamental mechanism of cell signaling. Protein kinases, also termed phosphotransferases, are the enzymes that catalyze the transfer of the $\gamma$ phosphate of a purine nucleotide triphosphate (i.e. ATP and GTP) to the hydroxyl groups of their protein substrates. Importantly, many of the major classes of receptors that trigger immune cell activation are linked to protein phosphorylation and physically associate with kinases. In fact, the first event in T cell receptor (TCR), B cell receptor (BCR), NK (natural killer) and Fc receptor signaling is phosphorylation of receptor subunits on tyrosine residues. Likewise, cytokine receptors, especially Type I/II cytokine receptors, signal directly by activating kinases, which phosphorylate receptor subunits and thereby initiate signaling. This has led to the idea that blocking kinases may be an effective way to block immune cell activation and, in turn, treat autoimmune disease. Multiple kinase inhibitors are now in clinical trials for rheumatoid arthritis, inflammatory bowel disease, psoriasis and other diseases. This is surely an area that will expand in the next few years, so it is appropriate to briefly review some of the key issues.

\section{Kinases: the first step in immune cell signaling}

There are 518 kinases in the human genome, divided into eight major groups. The first step in signaling by multi-chain immune recognition receptors, which include the TCR, BCR, Fc receptors and others, is tyrosine phosphorylation of the receptor itself and associated adapter molecules like LAT (linker for activation of $\mathrm{T}$ cells). This is mediated initially by Src family protein tyrosine kinases, followed by kinases such as Syk (spleen tyrosine kinase) or Zap-70, Tec family PTKs and later by serine-threonine kinases, such as mitogen activated protein kinases (MAPKs) and protein kinase C (PKC) family (see Figure 1). Initial protein phosphorylation ultimately links membrane events to calcium modulation, cytoskeletal rearrangement, gene transcription and other canonical features of lymphocyte action. Cytokines that use Type I and II cytokine receptors signal via the activation of receptor-associated Janus kinases (Jaks). 
Figure I. Proximal signaling pathways upon stimulation of immune receptors in B and T cells

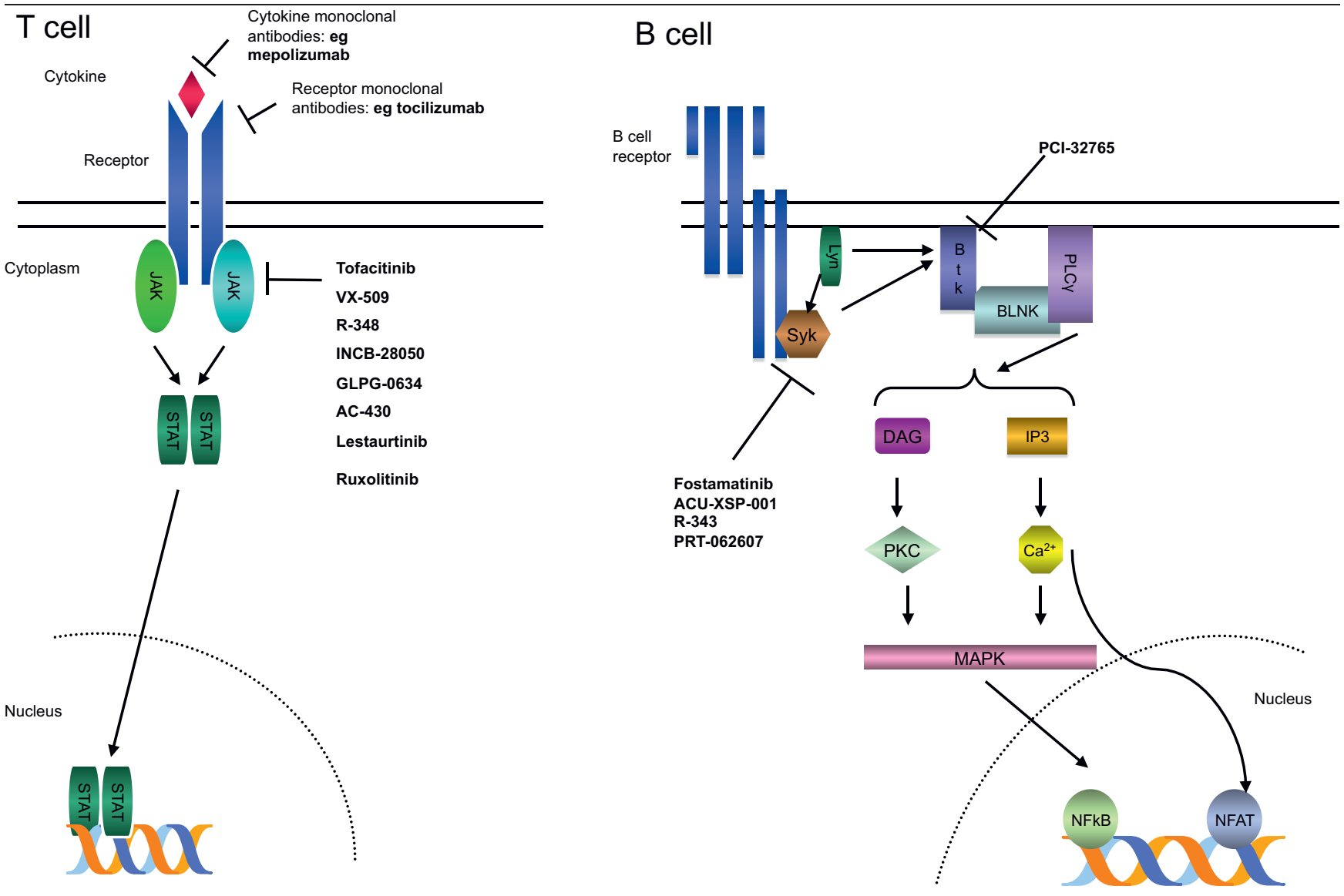

Type I and II cytokine receptors associate with Janus kinases (Jaks). Cytokine binding activates Jaks, which then phosphorylate cytokine receptors allowing STAT (signal transducer and activator of transcription) DNA-binding proteins to attach to receptors and become phosphorylated. STAT activation leads to their dimerization and translocation to the nucleus where they regulate gene expression. Targets along the signal transduction pathway, including specific kinase inhibitors, are shown (left). In B cells, antigen ligation leads to activation of three main protein tyrosine kinases (PTKs) — the Src-family kinases Lyn, Syk and the TEC-family kinase Btk. Syk phosphorylates adaptor protein BLNK and, along with Btk, activates PLC $\gamma$. Activation of PLC $\gamma$ leads to the release of intracellular $\mathrm{Ca}^{2+}$ and activation of protein kinase $C$ (PKC), which activate mitogen-activated protein kinases (MAPKs). The MAPK cascade activates transcription factors nuclear factor- $\kappa B$ (NF- $\kappa B$ ) and nuclear factor of activated T cells (NFAT), allowing gene regulation (right). Abbreviations: BLNK: B cell linker protein; MAPK, mitogen-activated protein kinase; NFAT, nuclear factor of activated T cells; NF- $k B$, nuclear factor- $k B$; PLC $\gamma$, Phospholipase $\gamma$; PIP3K, phosphatidylinositol triphosphate kinase; PKC, protein kinase C; STAT, signal transducer and activator of transcription; Syk: Spleen tyrosine kinase; DAG, diacylglycerol; IP3, inositol I,4,5-triphosphate.

Other cytokines, such as stem cell factor or transforming growth factor family cytokines, bind to receptors with intrinsic tyrosine or serine-threonine kinase properties respectively. Receptors for cytokines such as interleukin (IL)-1 and tumor necrosis factor (TNF) are not themselves directly associated with kinases, but they too link to downstream kinase cascades.

\section{Where it all started}

Since all protein kinases bind ATP, the prospect of developing a therapeutically useful kinase inhibitor seemed daunting, since many enzymes use ATP as a substrate, and the structure of protein kinases is highly conserved. Nonetheless, it is now appreciated that kinase inhibitors have become one of the most successful new categories of drugs. The story begins with the Abl tyrosine kinase. BCR-Abl is a fusion protein that results from a chromosomal translocation (Philadelphia chromosome) in patients with chronic myeloid leukemia (CML) and this kinase seemed to represent an ideal target, despite the caveats of targeting protein kinases [1]. In fact, the inhibitor imatinib has revolutionized the treatment of CML with relatively modest side effects [2]. Imatinib was subsequently shown to inhibit several unrelated tyrosine kinases $[3,4]$. In fact, these actions led to imatinib being used successfully in other 
malignancies, such as gastrointestinal stromal tumors, and the hypereosinophilic syndrome $[3,4]$, by inhibiting kinases Kit [5] and PDGFR [6]. The success of imatinib and the epidermal growth factor receptor inhibitors erlotinib and gefitinib led to the problem of tumors developing drug resistance associated with mutations in the targeted kinase [7]. This led to the development of new multikinase inhibitors such as dasatinib and sunitinib, which are also now FDA approved $[8,9]$. Currently, there are several small molecule kinase inhibitors in routine clinical use, all of which are FDA approved for oncologic indications (see Table 1).

\section{Targeting cytokine signaling by inhibiting Janus kinases}

The role of cytokines in mediating an immune response has made them attractive targets for immunomodulatory drug development. Consequently, monoclonal antibodies against cytokines (e.g. mepolizumab against IL-5) and cytokine receptors (e.g. tocilizumab against IL-6 receptor), as well as recombinant receptors, have been used successfully in the clinic [10]. Of note, a large subset of cytokines (roughly 60), which bind type I/II cytokine receptors and includes many interleukins, interferons, colony stimulating factors and other cytokines [11], has a shared mechanism of signal transduction. The Type I/II cytokine receptors bind Jaks, which are essential for signaling [12-14].

The importance in vivo of Jaks was first established by the identification of patients with immunodeficiency and $J A K 3$ mutations and by knockout mice. Mutation of JAK3 results in a severe combined immunodeficiency (SCID), characterized by an almost complete absence of $\mathrm{T}$ cells and NK cells, with defective B cells [15-18]. In contrast with other Jaks, JAK3 is primarily expressed in hematopoietically derived cells, where it is associated with the IL2 receptor common $\gamma$ chain $(\mathrm{c} \gamma \mathrm{c})$ and mediates signaling by IL-2, IL-4, IL-7, IL-9, IL-15 and IL-21, cytokines that are critical for the development and maturation of $\mathrm{T}$ cells [19]. The profound, but selective, phenotype associated with JAK3 deficiency led to the suggestion that targeting Jaks might be a strategy for the development of a new class of immunomodulatory drugs [20].

\section{JAK inhibitors in the clinic Tofacitinib}

Tofacitinib, formerly designated CP-690,550, was one of the first JAK inhibitors to enter the clinic. It inhibits JAK3 and JAK1 and, to a lesser extent, JAK2, but has little effect

Table I. US FDA-approved kinase inhibitors

\begin{tabular}{|c|c|c|}
\hline Agent & Targets for therapeutic activity & US FDA-approved indication \\
\hline \multicolumn{3}{|c|}{ Direct kinase inhibitors by competing for the ATP-binding pocket } \\
\hline Imatinib & BCR-ABL, PDGFR and KIT & CML and GIST \\
\hline Dasatinib & $B C R-A B L$ & CML \\
\hline Nilotinib & $B C R-A B L$ & CML \\
\hline Gefitinib & EGFR & Non-small cell lung cancer \\
\hline Erlotinib & EGFR & Non-small cell lung cancer and pancreatic cancer \\
\hline Lapatinib & EGFR and ERBB2 & Breast cancer \\
\hline Sunitinib & VEGFR2, PDGFR and KIT & Renal cell carcinoma, GIST, pancreatic cancer \\
\hline Sorafenib & VEGFR2 and PDGFR & Renal cell carcinoma and hepatocellular carcinoma \\
\hline Pazopanib & VEGFR2, PDGFR and KIT & Renal cell carcinoma \\
\hline Crizotinib & ALK/c-MET & Non-small cell lung cancer \\
\hline Vemurafenib & BRAF & Melanoma \\
\hline Vandetanib & VEGFR-2, EGFR, RET and ErbB-I & Medullary thyroid cancer \\
\hline Ruxolitinib & JAKI/JAK2 & Myelofibrosis \\
\hline \multicolumn{3}{|c|}{ Indirect kinase inhibitors by binding to FK506 binding protein I2 (FKBPI2) } \\
\hline Sirolimus & mTOR & Solid organ and bone marrow transplantation \\
\hline Everolimus & mTOR & Renal cell carcinoma, Subependymal Giant Cell \\
\hline & & Astrocytoma (SEGA) associated with Tuberous \\
\hline & & Sclerosis (TS) and Progressive Neuroendocrine \\
\hline & & Tumors of Pancreatic Origin (PNET) \\
\hline Temsirolimus & mTOR & Renal cell carcinoma \\
\hline \multicolumn{3}{|c|}{ Monoclonal antibodies binding to receptor tyrosine kinases } \\
\hline Trastuzumab & ERBB2 & Breast cancer \\
\hline Cetuximab & EGFR & $\begin{array}{l}\text { Colorectal cancer, and squamous carcinoma of } \\
\text { head and neck }\end{array}$ \\
\hline Panitumumab & EGFR & Colorectal cancer \\
\hline Bevacizumab & VEGF & $\begin{array}{l}\text { Colorectal cancer, non-small cell lung cancer, } \\
\text { breast cancers, glioblastoma and renal cell } \\
\text { carcinoma }\end{array}$ \\
\hline
\end{tabular}

Abbreviations: CML, chronic myeloid leukemia; EGFR, epidermal growth factor receptor; FDA, Food and Drug Administration; GIST, gastrointestinal stromal tumor; PDGFR, platelet-derived growth factor receptor; VEGFR2, vascular endothelial growth factor receptor 2. 
on TYK2 $[13,21]$. Consequently, tofacitinib potently inhibits c $\gamma$ c cytokines but also blocks IFN- $\gamma$, IL- 6 and, to a lesser extent, IL-12 and IL-23. Functionally, tofacitinib affects both innate and adaptive immune responses by inhibiting pathogenic Th17 cells and Th1 and Th2 cell differentiation [13]. In Phase II trials in rheumatoid arthritis, tofacitinib as monotherapy met the American College of Rheumatology 20\% improvement (ACR20) criteria in $61-70 \%$ of patients at doses between 5 and $15 \mathrm{mg}$ twice daily [22]. These results were replicated in phase III trials at doses 5 and $10 \mathrm{mg}$ twice daily [23]. In com-bination with methotrexate, tofacitinib met its primary endpoint (pre-agreed measure of success) in a highly active disease group [24,25]. Additionally, tofacitinib significantly reduced progression of structural damage compared with placebo in patients with active rheumatoid arthritis on methotrexate [26]. Tofacitinib was also found to be beneficial in patients with rheumatoid arthritis who were refractory to biologics [27]. Tofacitinib is also under clinical investigation for psoriasis, inflammatory bowel disease and prevention of transplant rejection.

The major adverse effects of tofacitinib include increased incidence of infections and increased low density lipoprotein levels; however, the incidence of infection with opportunistic organisms appears to be limited [28]. The former is perhaps expected given the roles of diverse cytokines in host defense. The latter is likely related to inhibition of IL-6 signaling [29]. Anemia and neutropenia were also reported [30], presumably related to JAK2 inhibition and interference with cytokines, such as erythropoietin and colony stimulating factors [31]. Little reduction in $\mathrm{CD}^{+} \mathrm{T}$ cells has been seen, but significant reduction in NK cells and $\mathrm{CD} 8^{+} \mathrm{T}$ cells does occur, with an as yet undetermined infection risk $[32,33]$. Thus, the major adverse effects of tofacitinib appear to be consequences of blocking cytokine signaling as one might expect, and seemingly not related to off-target effects. The balance of efficacy and safety of tofacitinib compared to standard of care therapy will need to be ascertained in clinical trials and, if approved, ultimately in the routine clinical use of these drugs.

\section{VX-509}

VX-509 is another inhibitor designed to selectively inhibit Jak3. A phase IIa study has just been completed and, like tofacitinib, use of VX-509 was also associated with a dose-dependent increase in clinical response in rheumatoid arthritis.

\section{GLPG0634}

The results of a Phase II trial of a selective Jak1 inhibitor GLPG0634 have also been released, and it too is efficacious and causes no unexpected adverse advents.

\section{Ruxolitinib}

As gene targeting of either Jak1 or Jak2 in mice was embryonically lethal, it was thought that pharmacological inhibition might be problematic. However, the discovery that JAK2 gain-of-function mutations underlie polycythemia vera and myelofibrosis provided the impetus to purposely target JAK2. This led to the development of the drug, ruxolitinib, which blocks JAK1 and JAK2. In a phase II study, patients receiving ruxolitinib for myelofibrosis showed significant clinical improvement. Despite the drug's ability to block both JAK1 and JAK2, it was well tolerated [34]. In addition, efficacy was seen in patients that did not exhibit JAK2 mutations, suggesting that the drug might be affecting kinases other than JAK2. This drug was recently approved by the FDA for treatment of myelofibrosis.

As cyc cytokines employ both JAK1 and JAK3 for signaling, ruxolitinib and tofacitinib will block many of the same cytokines. It is therefore of interest to note that, in a phase II study in rheumatoid arthritis, ruxolinitib had efficacy that was not dissimilar from tofacitinib [35].

\section{INCB028050}

Another selective JAK1 and JAK2 inhibitor, INCB028050, showed dose-dependent efficacy in active rheumatoid arthritis patients refractory to disease-modifying drugs and biologics, with the most frequent side effects being headache, upper respiratory infections and diarrhea [36].

\section{Other JAK inhibitors}

Other JAK inhibitors are also in development and clinical trials for oncologic [37-49] and autoimmune indications [50]are ongoing (see Table 2). The comparative efficacy and toxicity of the various JAK inhibitors will be important to follow in longer-term studies.

\section{Targeting other kinases}

Despite their scientific appeal, multiple attempts to generate clinically useful p38 MAPK inhibitors have generally failed, either due to toxicity or inadequate efficacy. Only one compound, VX-702, yielded a modest effect on clinical signs and symptoms in rheumatoid arthritis and a transient effect on biomarkers of inflammation [51].

Zap70 or Syk mediate signals from receptors that contain immunoreceptor tyrosine-based motifs (ITAMs) (Figure 1). Like JAK3, Zap70 deficiency also causes SCID, but in this case there is preferential loss of CD8+ T cells [52]. For this reason, Zap70 is a rational target; unfortunately, a clinically useful compound has not emerged. In contrast, the Syk 
Table 2. Kinase inhibitors in development for autoimmunity

\begin{tabular}{lll}
\hline Agent & Targets for therapeutic activity & Indication/Phase \\
\hline Tofacitinib & JAK3/JAKI/JAK2 & RA/Phase III \\
& & Psoriasis/Phase II \\
IBD/Phase II \\
VX-509 & JAK3 & RA/Phase II \\
R-348 & JAK3 & RA/Phase I \\
Ruxolitinib & JAKI/JAK2 & Psoriasis/Phase II \\
INCB-028050 & JAKI/JAK2 & RA/Phase II \\
GLPG-0634 & JAKI/JAK2/TYK2 & RA/Phase II \\
AC-430 & JAK2 & RA/Phase I \\
& & Lymphoma/Phase I \\
Lestaurtinib & FLT3/TrkA/JAK2 & AML/Phase III \\
& & Psoriasis/Phase II \\
Fostamatinib & & Pancreatic cancer/Phase II \\
& Syk/FLT3/KIT/LCK & RA/Phase III \\
ACU-XSP-00I & & NHL/Phase I/II \\
R-343 & & CLL/Phase I/II \\
PRT-062607 & Syk & Asthma/Phase II \\
& Syk & Asthma/Phase I \\
Sotrastaurin (AEB07I) & RA/Phase I \\
& & CLL/Phase I \\
& PKC & NHL/Phase I \\
PLX 5622 & & Psoriasis/Phase II \\
& & IBD/Phase II \\
& & Solid organ transplantation/Phase II \\
& & Diffuse Large B-Cell Lymphoma/Phase I \\
& CSF/Phase I
\end{tabular}

Abbreviations: ACU-XSP-00I, small interfering RNA that silences Syk gene; CLL, chronic lymphoid leukemia; CSFI, colony stimulating factor I receptor; FLT3, ms-related tyrosine kinase 3; NHL, non-Hodgkin lymphoma; PKC, protein kinase C; TrkA, aka high affinity nerve growth factor receptor or neurotrophic tyrosine kinase receptor type I or TRKI-transforming tyrosine kinase protein.

inhibitor, fostamatinib, has been found to have efficacy in a Phase II study in rheumatoid arthritis [53]. Fostamatinib also targets FLT3, KIT, LCK among other kinases, possibly contributing to its clinical benefit [54]. Toxicities include diarrhea, infections, neutropenia and hypertension. A subsequent study, involving patients refractory to biologics, failed to meet its primary endpoint; however, this was attributed to study design issues [55]. Because of its critical role in B cell function, another logical target is Tec family member Btk. Such inhibitors are first being used in the setting of B cell lymphoma, but could be useful in autoimmune diseases as well.

Members of the PKC family are activated downstream of a variety of key immunologic receptors. One PKC inhibitor, sotrastaurin, has been tested in kidney allograft rejection, and showed moderate efficacy but less nephrotoxicity compared with calcineurin inhibitor regimens [56]. Phase I and II trials on inflammatory bowel disease, psoriasis [57] and Diffuse Large B-Cell Lymphoma are ongoing.

Colony stimulating factor 1 receptor (c-Fms) is a transmembrane receptor tyrosine kinase. A phase 1 trial of a CSF1R inhibitor (PLX5622) in rheumatoid arthritis is ongoing.

\section{Conclusions and future prospects}

The last few years have produced great advances in deciphering the mechanisms involved in intracellular signaling pathways. Consequently, our understanding of the molecular basis of immune cell activation is vastly more sophisticated. These advances have been associated with the identification of effective, safe kinase inhibitors. Many of these agents were developed for the treatment of cancer, and the pleiotropic effects of kinase inhibitors, initially thought of as a disadvantage, have proved to be beneficial. The use of kinase inhibitors has expanded beyond malignancies to autoimmune diseases with favourable safety profile. Also, multikinase inhibitors that have broad effects have been less problematic than one might have envisioned, but it is too early for us to know how useful such inhibitors will be in the treatment of immune-mediated disease. Highly selective kinase inhibitors, such as p38 MAPK inhibitors, have been disappointing in the treatment of autoimmune diseases, either due to toxicity and/or lack of efficacy. Whether broad spectrum, multi-kinase inhibitors or highly selective second and third generation kinase inhibitors will ultimately be more efficacious and safe remains to be established. The issue of acquired resistance, while a very real problem in oncology, presumably will not be a major issue in autoimmune diseases. 
At this point, it seems likely that we will see the development of many more immunosuppressants that inhibit kinases expressed in immune cells. It will also not be a surprise if many drugs that enter clinical use as treatments for cancer are found to be efficacious in the treatment of autoimmune disease or transplant rejection. There is ample precedent for this with drugs such as cyclophosphamide, azathioprine and methotrexate. It also bears pointing out that not all kinase inhibitors exert their effect by competing for ATP in the kinase domain. A prime example is the drug rapamycin (also called sirolimus), as an approved immunosuppressant effective for allograft rejection and graft versus host disease [5861]. It binds FK binding protein 12 and mammalian target of rapamycin (mTOR) complex 1 and indirectly inhibits the kinase mTOR [62-65], a kinase that is activated by a number of growth factor receptors and cytokines [66]. Thus, indirectly inhibiting kinases by targeting their associated complexes is another effective strategy for developing drugs. Regardless, the number of kinase inhibitors and the range of clinical indications are likely to expand dramatically in the next few years. Precisely how these drugs are used in combination with or in place of other therapies such as biologics, steroids, etc. remains to be determined.

\section{Abbreviations}

TCR, T cell receptor; BCR, B cell receptor; NK, natural killer; PKC, protein kinase C; JAK, Janus kinase; IL, interleukin; $\mathrm{TNF}$, tumor necrosis factor; $\mathrm{CML}$, chronic myeloid leukemia; SCID, severe combined immunodeficiency; MAPK, mitogen-activated protein kinase; Syk, spleen tyrosine kinase; ITAMs, immunoreceptor tyrosine based motifs; mTOR, mammalian target of rapamycin.

\section{Competing Interests}

J.O'S and National Institutes of Health (NIH) hold patents related to targeting JAKs as targets for immunomodulatory agents. J. O'S and the NIH have a Collaborative Research Agreement and Development Award with Pfizer.

\section{References}

I. Sawyers CL: Chronic myeloid leukemia. N Engl J Med 1999, 340: $1330-40$.

2. Mughal TI, Goldman JM: Chronic myeloid leukemia: current status and controversies. Oncology (Williston Park) 2004, I 8:837-44, 847; discussion 847-50, 853-34.

3. Druker BJ, Lydon NB: Lessons learned from the development of an abl tyrosine kinase inhibitor for chronic myelogenous leukemia. J Clin Invest 2000, 105:3-7.

4. Buchdunger E, Cioffi CL, Law N, Stover D, Ohno-Jones S, Druker BJ, Lydon NB: Abl protein-tyrosine kinase inhibitor STI57I inhibits in vitro signal transduction mediated by c-kit and platelet-derived growth factor receptors. J Pharmacol Exp Ther 2000, 295: 139-45.
5. Demetri GD, von Mehren M, Blanke CD, Van den Abbeele AD, Eisenberg B, Roberts PJ, Heinrich MC, Tuveson DA, Singer S, Janicek M, Fletcher JA, Silverman SG, Silberman SL, Capdeville R, Kiese B, Peng B, Dimitrijevic S, Druker BJ, Corless C, Fletcher CD, Joensuu $H$ : Efficacy and safety of imatinib mesylate in advanced gastrointestinal stromal tumors. N Engl J Med 2002, 347:472-80.

6. Cools J, DeAngelo DJ, Gotlib J, Stover EH, Legare RD, Cortes J, Kutok J, Clark J, Galinsky I, Griffin JD, Cross NC, Tefferi A, Malone J, Alam R, Schrier SL, Schmid J, Rose M, Vandenberghe P, Verhoef G, Boogaerts M, Wlodarska I, Kantarjian H, Marynen P, Coutre SE, Stone R, Gilliland DG: A tyrosine kinase created by fusion of the PDGFRA and FIPILI genes as a therapeutic target of imatinib in idiopathic hypereosinophilic syndrome. $N$ Engl J Med 2003, 348:|20I-I4.

FI000 Factor 12

Evaluated by Peter Weller 03 Apr 2003, Richard L Stevens OI Apr 2003

7. Druker BJ: Circumventing resistance to kinase-inhibitor therapy. N Engl J Med 2006, 354:2594-6.

8. Shayani S: Dasatinib, a multikinase inhibitor: therapy, safety, and appropriate management of adverse events. Ther Drug Monit 32:680-7.

9. Pal SK, Figlin RA, Yu H: Deciphering the anticancer mechanisms of sunitinib. Cancer Biol Ther 10:712-4.

10. Nishimoto N, Kishimoto T: Interleukin 6: from bench to bedside. Nat Clin Pract Rheumatol 2006, 2:619-26.

I I. Leonard WJ: Role of Jak kinases and STATs in cytokine signal transduction. Int J Hematol 200I, 73:27I-7.

12. Pesu M, Candotti F, Husa M, Hofmann SR, Notarangelo LD, O'Shea J]: Jak3, severe combined immunodeficiency, and a new class of immunosuppressive drugs. Immunol Rev 2005, 203:I27-42.

13. Ghoreschi K, Jesson MI, Li X, Lee JL, Ghosh S, Alsup JW, Warner JD, Tanaka M, Steward-Tharp SM, Gadina M, Thomas CJ, Minnerly JC, Storer CE, LaBranche TP, Radi ZA, Dowty ME, Head RD, Meyer DM, Kishore N, O'Shea J): Modulation of Innate and Adaptive Immune Responses by Tofacitinib (CP-690,550). J. Immunol, I 86:4234-43.

14. Yamaoka K, Saharinen P, Pesu M, Holt VE, 3rd, Silvennoinen O, O'Shea JJ: The Janus kinases (Jaks). Genome Biol 2004, 5:253.

I5. Vosshenrich CA, Di Santo JP: Interleukin signaling. Curr Biol 2002, I 2:R760-3.

16. Leonard WJ, Lin JX: Cytokine receptor signaling pathways. J Allergy Clin Immunol 2000, I 05:877-88.

17. Buckley RH, Schiff RI, Schiff SE, Markert ML, Williams LW, Harville TO, Roberts JL, Puck JM: Human severe combined immunodeficiency: genetic, phenotypic, and functional diversity in one hundred eight infants. J Pediatr 1997, 130:378-87.

18. Pesu M, O'Shea J, Hennighausen L, Silvennoinen O: Identification of an acquired mutation in Jak2 provides molecular insights into the pathogenesis of myeloproliferative disorders. Mol Interv 2005, 5:21|-5.

19. Leonard WJ, O'Shea J]: Jaks and STATs: biological implications. Annu Rev Immunol 1998, I 6:293-322.

20. O'Shea J, Pesu M, Borie DC, Changelian PS: A new modality for immunosuppression: targeting the JAK/STAT pathway. Nat Rev Drug Discov 2004, 3:555-64.

21. Karaman MW, Herrgard S, Treiber DK, Gallant P, Atteridge CE, Campbell BT, Chan KW, Ciceri P, Davis MI, Edeen PT, Faraoni R, Floyd M, Hunt JP, Lockhart DJ, Milanov ZV, Morrison MJ, Pallares G, Patel HK, Pritchard S, Wodicka LM, Zarrinkar PP: A quantitative analysis of kinase inhibitor selectivity. Nat Biotechnol 2008 , 26: $127-32$.

FI000 Factor 6

Evaluated by Ruedi Aebersold 25 Feb 2008

22. Kremer JM, Bloom BJ, Breedveld FC, Coombs JH, Fletcher MP, Gruben D, Krishnaswami S, Burgos-Vargas R, Wilkinson B, 
Zerbini CA, Zwillich SH: The safety and efficacy of a JAK inhibitor in patients with active rheumatoid arthritis: Results of a double-blind, placebo-controlled phase lla trial of three dosage levels of CP-690,550 versus placebo. Arthritis Rheum 2009, 60:1895-905.

\section{FI000 Factor 6}

Evaluated by John O'shea 13 Feb 2012

23. Fleischmann JK R, Connell CA, Benda B, Bradley JD, Gruben D, Zwillich SH, Kanik KS: A phase 3 study of oral jak inhibitor tofacitinib (cp-690,550) monotherapy in patients with active rheumatoid arthritis: subgroup analysis of efficacy. Ann Rheum Dis 201 I, 70(Suppl3):600.

24. Kremer JM, Cohen S, Wilkinson BE, Connell CA, French JL, GomezReino J, Gruben D, Kanik KS, Krishnaswami S, Pascual-Ramos V, Wallenstein G, Zwillich SH: Safety and Efficacy After 24 Week (WK) Dosing of the Oral JAK Inhibitor CP-690,550 (CP) in Combination with Methotrexate (MTX) in Patients (PTS) with Active Rheumatoid Arthritis (RA). Arthritis Rheum 2009, 60 (Suppl 10): 1925

25. Kremer Z-GL J, Hall S, Fleischmann R, Genovese M, Martin-Mola E, Isaacs J, Gruben D, Wallenstein G, Krishnaswami S, Zwillich S, Koncz T, Riese R, Bradley J: Tofacitinib (cp-690,550), an oral jak inhibitor, in combination with traditional dmards: phase 3 study in patients with active rheumatoid arthritis with inadequate response to dmards. Ann Rheum Dis 2011, 70 (Suppl3): 170.

26. Désirée van der Heijde YT, Fleischmann Roy, Keystone Edward C, Kremer JM, Zerbini CA F, Cardiel M, Cohen SB, Nash PT, Song Yeong Wook, Tegzova D, Wyman B, Gruben D, Benda B, Wallenstein G, Zwillich SH, Bradley JD, Connell CA and the ORAL Scan investigators: Tofacitinib (CP-690,550), An Oral Janus Kinase Inhibitor, in Combination with Methotrexate Reduced the Progression of Structural Damage in Patients with Rheumatoid Arthritis: a 24-Month Phase 3 Study. Arthritis Rheum 201I, 2592.

27. Burmester RB Gerd-Rüdiger, Charles-Schoeman C, Wollenhaupt J, Zerbini CA F, Benda B, Gruben D, Wallenstein G, Krishnaswami S, Zwillich SH, Koncz T, Bradley JD, Mebus CA and the ORAL Step investigators: Tofacitinib (CP-690,550), An Oral Janus Kinase Inhibitor, in Combination with Methotrexate, in Patients with Active Rheumatoid Arthritis with An Inadequate Response to Tumor Necrosis Factor-Inhibitors: A 6-Month Phase 3 Study. Arthritis Rheum 2011, 7I8.

28. van Gurp EA, Schoordijk-Verschoor W, Klepper M, Korevaar SS, Chan G, Weimar W, Baan CC: The effect of the JAK inhibitor CP-690,550 on peripheral immune parameters in stable kidney allograft patients. Transplantation 2009, 87:79-86.

29. Mclnnes K, Lee Mandel, Song Connell, Luo Brosnan, Zwillich Bradley: Phase 2 study of the effects of open-label tofacitinib (cp690,550 ) and double-blind atorvastatin on lipids in patients with active rheumatoid arthritis. Ann Rheum Dis 20II, 70(Suppl 3): 169.

30. Kremer J: JAK inhibition in patients with rheumatoid arthritis: evidence from phase 2 and 3 trials. Ann Rheum Dis 201 I, 70(Suppl 3):33.

31. Borie DC, Larson MJ, Flores MG, Campbell A, Rousvoal G, Zhang S, Higgins JP, Ball DJ, Kudlacz EM, Brissette WH, Elliott EA, Reitz BA, Changelian PS: Combined use of the JAK3 inhibitor CP-690,550 with mycophenolate mofetil to prevent kidney allograft rejection in nonhuman primates. Transplantation 2005, 80:1756-64.

32. Paniagua R, Si MS, Flores MG, Rousvoal G, Zhang S, Aalami $O$, Campbell A, Changelian PS, Reitz BA, Borie DC: Effects of JAK3 inhibition with CP-690,550 on immune cell populations and their functions in nonhuman primate recipients of kidney allografts. Transplantation 2005, 80:1283-92.

FI000 Factor 6

Evaluated by John O'shea 13 Feb 2012

33. Conklyn M, Andresen C, Changelian P, Kudlacz E: The JAK3 inhibitor CP-690550 selectively reduces NK and CD8+ cell numbers in cynomolgus monkey blood following chronic oral dosing. J Leukoc Biol 2004, 76: 1248-55.

FI000 Factor 6

Evaluated by John O'shea 13 Feb 2012

34. Verstovsek S, Kantarjian H, Mesa RA, Pardanani AD, Cortes-Franco J, Thomas DA, Estrov Z, Fridman JS, Bradley EC, Erickson-Viitanen S, Vaddi K, Levy R, Tefferi A: Safety and efficacy of INCBOI8424, a JAKI and JAK2 inhibitor, in myelofibrosis. $N$ Engl J Med, 363: $1117-27$.

FI000 Factor 6

Evaluated by John O'shea 13 Feb 2012

35. Williams W, Scherle P, Shi J, Newton R, McKeever E, Fridman J, Burn T, Vaddi K, Levy R: A randomized placebo-controlled study of INCBO I8424, a selective Janus kinase I \& 2 (JAKI \& 2) inhibitor in rheumatoid arthritis (RA). Arthritis Rheum 2008, 58 (Abstr. 7|4).

36. Greenwald MF-GR, Levy R, Liang J, Vaddi K, Williams W, Newton R, Yeleswaram S, Flores R, McKeever E, Rodgers J, Shepard S, Berclaz P-Y, Lee CH, Luchi M: A Randomized Dose-Ranging, PI aceboControlled Study of INCB028050, a Selective JAKI and JAK2 Inhibitor in Subjects with Active Rheumatoid Arthritis. Arthritis Rheum 2010, 62(10 Suppl):9| I-4.

FI000 Factor 6

Evaluated by John O'shea 13 Feb 2012

37. Pardanani A, Gotlib JR, Jamieson C, Cortes JE, Talpaz M, Stone RM, Silverman MH, Gilliland DG, Shorr J, Tefferi A: Safety and efficacy of TGI0I348, a selective JAK2 inhibitor, in myelofibrosis. J Clin Oncol, 29:789-96.

FI000 Factor 7

Evaluated by Richard Larson and Toyosi Odenike 09 Aug 2011, Ruben Mesa 09 May 2011.

38. Shide K, Kameda T, Markovtsov V, Shimoda HK, Tonkin E, Fang S, Liu C, Gelman M, Lang W, Romero J, McLaughlin J, Bhamidipati S, Clough J, Low C, Reitsma A, Siu S, Pine P, Park G, Torneros A, Duan M, Singh R, Payan DG, Matsunaga T, Hitoshi Y, Shimoda K: R723, a selective JAK2 inhibitor, effectively treats JAK2V6I7F-induced murine myeloproliferative neoplasm. Blood, I I 7:6866-75.

39. Tyner JW, Bumm TG, Deininger J, Wood L, Aichberger KJ, Loriaux MM, Druker BJ, Burns C], Fantino E, Deininger MW: CYT387, a novel JAK2 inhibitor, induces hematologic responses and normalizes inflammatory cytokines in murine myeloproliferative neoplasms. Blood, I I 5:5232-40.

40. Stump KL, Lu LD, Dobrzanski P, Serdikoff C, Gingrich DE, Dugan BJ, Angeles TS, Albom MS, Ator MA, Dorsey BD, Ruggeri BA, Seavey MM: A highly selective, orally active inhibitor of Janus kinase 2, CEP-33779, ablates disease in two mouse models of rheumatoid arthritis. Arthritis Res Ther, 13:R68.

4I. Ahmed KB, Warner SL, Chen A, Gourley ES, Liu X, Vankayalapati H, Nussenzveig R, Prchal JT, Bearss DJ, Parker CJ: In vitro and in vivo characterization of SGI-1252, a small molecule inhibitor of JAK2. Exp Hematol, 39: 14-25.

42. Dawson MA, Curry JE, Barber K, Beer PA, Graham B, Lyons JF, Richardson CJ, Scott MA, Smyth T, Squires MS, Thompson NT, Green AR, Wallis NG: AT9283, a potent inhibitor of the Aurora kinases and Jak2, has therapeutic potential in myeloproliferative disorders. Br J Haematol, 150:46-57.

43. Quintas-Cardama A, Kantarjian H, Cortes J, Verstovsek S: Janus kinase inhibitors for the treatment of myeloproliferative neoplasias and beyond. Nat Rev Drug Discov, 10:127-40.

44. Santos FP, Kantarjian H, McConkey D, O'Brien S, Faderl S, Borthakur G, Ferrajoli A, Wright J, Cortes J: Pilot study of bortezomib for patients with imatinib-refractory chronic myeloid leukemia in chronic or accelerated phase. Clin Lymphoma Myeloma Leuk, I I:355-60.

45. Diaz T, Navarro A, Ferrer G, Gel B, Gaya A, Artells R, Bellosillo B, Garcia-Garcia M, Serrano S, Martínez A, Monzo M: Lestaurtinib 
inhibition of the Jak/STAT signaling pathway in hodgkin lymphoma inhibits proliferation and induces apoptosis. PLOS One, 6:el 8856.

46. Thoma G, Nuninger F, Falchetto R, Hermes E, Tavares GA, Vangrevelinghe E, Zerwes HG: Identification of a Potent Janus Kinase 3 Inhibitor with High Selectivity within the Janus Kinase Family. J Med Chem, 54:248-8.

47. Kim BH, Jee JG, Yin CH, Sandoval C, Jayabose S, Kitamura D, Bach EA, Baeg GH: NSCII4792, a novel small molecule identified through structure-based computational database screening, selectively inhibits JAK3. Mol Cancer, 9:36.

48. Velotta JB, Deuse T, Haddad M, Masuda E, Park G, Carroll D, Taylor V, Robbins RC, Schrepfer S: A novel JAK3 inhibitor, R348, attenuates chronic airway allograft rejection. Transplantation 2009, 87:653-9.

49. Steele AJ, Prentice AG, Cwynarski K, Hoffbrand AV, Hart SM, Lowdell MW, Samuel ER, Wickremasinghe RG: The JAK3-selective inhibitor PF-956980 reverses the resistance to cytotoxic agents induced by interleukin-4 treatment of chronic lymphocytic leukemia cells: potential for reversal of cytoprotection by the microenvironment. Blood, I l 6:4569-77.

50. van't Klooster GAE VRL, Menet $C$, Namour F, Vanhoutte $F$, van der Aar E, Clement-Lacroix P, Galien R, Nelles L, Guerin C, Smets B, Brys R, Feyen J, Wigerinck P: Preclinical and early clinical evaluation of GLPG0634, a combined JAK/TYK2 inhibitor for treatment of rheumatoid arthritis. Ann Rheum Dis 201I, 70 (Suppl 3):603.

5I. Damjanov N, Kauffman RS, Spencer-Green GT: Efficacy, pharmacodynamics, and safety of VX-702, a novel p38 MAPK inhibitor, in rheumatoid arthritis: results of two randomized, double-blind, placebo-controlled clinical studies. Arthritis Rheum 2009, 60:|232-4|.

FI000 Factor 6

Gary Firestein and Susan Sweeney 27 Jul 2009

52. Chan AC, Kadlecek TA, Elder ME, Filipovich AH, Kuo WL, Iwashima M, Parslow TG, Weiss A: ZAP-70 deficiency in an autosomal recessive form of severe combined immunodeficiency. Science 1994, 264:1599-601.

53. Weinblatt M, Kavanaugh A, Genovese M, Musser T, Grossbard E, Magilavy D: An oral spleen tyrosine kinase (Syk) inhibitor for rheumatoid arthritis. N Eng J Med, 363:1303-I2.

FI000 Factor 6

Evaluated by John O'shea 13 Feb 2012

54. Jakus Z, Simon E, Balazs B, Mocsai A: Genetic deficiency of Syk protects mice from autoantibody-induced arthritis. Arthritis Rheum, 62:1899-910.

FI000 Factor 6

Evaluated by John O'shea 13 Feb 2012

55. Genovese MC, Kavanaugh A, Weinblatt ME, Peterfy C, DiCarlo J, White ML, O'Brien M, Grossbard EB, Magilavy DB: An oral Syk kinase inhibitor in the treatment of rheumatoid arthritis: a three-month randomized, placebo-controlled, phase II study in patients with active rheumatoid arthritis that did not respond to biologic agents. Arthritis Rheum, 63:337-45.

56. Friman S, Arns W, Nashan B, Vincenti F, Banas B, Budde K, Cibrik D, Chan L, Klempnauer J, Mulgaonkar S, Nicholson M, Wahlberg J,
Wissing K-M, Abrams K, Witte S, Woodle ES: Sotrastaurin, a novel small molecule inhibiting protein-kinase $C$ : randomized phase II study in renal transplant recipients. Am J Transplant 20I I, I I:I444-55.

57. Skvara H, Dawid M, Kleyn E, Wolff B, Meingassner JG, Knight H, Dumortier T, Kopp T, Fallahi N, Stary G, Burkhart C, Grenet O, Wagner J, Hijazi Y, Morris RE, McGeown C, Rordorf C, Griffiths CE, Stingl G, Jung T: The PKC inhibitor AEB07I may be a therapeutic option for psoriasis. J Clin Invest 2008, I I 8:3 I 5 I-9.

58. Kreis H, Cisterne JM, Land W, Wramner L, Squifflet JP, Abramowicz D, Campistol JM, Morales JM, Grinyo JM, Mourad G, Berthoux FC, Brattström C, Lebranchu Y, Vialtel P: Sirolimus in association with mycophenolate mofetil induction for the prevention of acute graft rejection in renal allograft recipients. Transplantation 2000, 69:1252-60.

FI000 Factor 6

Evaluated by John O'shea I3 Feb 2012

59. Kahan BD: Efficacy of sirolimus compared with azathioprine for reduction of acute renal allograft rejection: a randomised multicentre study. The Rapamune US Study Group. Lancet 2000, 356:194-202.

FI000 Factor 6

Evaluated by John O'shea 13 Feb 2012

60. Gupta P, Kaufman S, Fishbein TM: Sirolimus for solid organ transplantation in children. Pediatr Transplant 2005, 9:269-76.

FI000 Factor 6

Evaluated by John O'shea 13 Feb 2012

61. Perez-Simon JA, Sanchez-Abarca I, Diez-Campelo M, Caballero D, San Miguel J: Chronic graft-versus-host disease: Pathogenesis and clinical management. Drugs 2006, 66:104I-57.

62. Edinger $A L$, Thompson $C B$ : Akt maintains cell size and survival by increasing mTOR-dependent nutrient uptake. Mol Biol Cell 2002, 13:2276-88.

FI000 Factor 6

Evaluated by John O'shea 13 Feb 2012

63. Harris TE, Lawrence JC Jr.: TOR signaling. SCi STKE 2003, 2003: rel5.

64. Hara K, Maruki $Y$, Long X, Yoshino K, Oshiro N, Hidayat S, Tokunaga C, Avruch J, Yonezawa K: Raptor, a binding partner of target of rapamycin (TOR), mediates TOR action. Cell 2002, I 10:177-89.

65. Kim DH, Sarbassov DD, Ali SM, King JE, Latek RR, ErdjumentBromage $H$, Tempst $P$, Sabatini DM: mTOR interacts with raptor to form a nutrient-sensitive complex that signals to the cell growth machinery. Cell 2002, I I0:163-75.

FI000 Factor 15

Evaluated by John O'shea I3 Feb 2012, Peter Taylor 29 Aug 2002,

Ernst Hafen 28 Aug 2002, Surender Kharbanda 07 Aug 2002, Sally Kornbluth 06 Aug 2002, Angus Nairn 30 Jul 2002.

66. Brennan P, Babbage JW, Thomas G, Cantrell D: p70(s6k) integrates phosphatidylinositol 3-kinase and rapamycin-regulated signals for E2F regulation in T lymphocytes. Mol Cell Biol 1999, 19:4729-38. 